\title{
Evaluation of volatile constituents, exudation of resin and occurrence of galls of Protium aracouchini (Aubl.) Marchand
}

\author{
Thiago Augusto Araujo Correia Lima ${ }^{a}$ in memorian), Leonardo Pinto Cunha ${ }^{\bullet}$, José Eduardo Lahoz da Silva

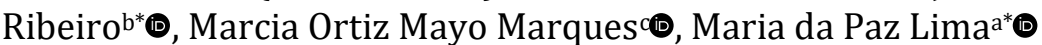 \\ a Instituto Nacional de Pesquisas da Amazônia, Manaus, 69067-375, Amazonas, Brasil.*mdapaz@inpa.gov.br \\ b Universidade Estadual de Londrina, Londrina, 86057970, Paraná, Brasil. \\ c Instituto Agronômico de Campinas, Campinas, 13012-970, São Paulo, Brasil.
}

Received: July 28, 2021 / Accepted: September 20, 2021 / Published online: September 30, 2021

\begin{abstract}
Protium aracouchini (Aubl.) Marchand [sin Icica aracouchini Aubl.], which occurs in the Adolpho Ducke Forest Reserve, in the Brazilian Amazon, was evaluated for the presence of galls, for resin exudation and the composition of the essential oils from the aerial parts and the resin. The experiment to stimulate the exudation of resin from the trunk was conducted using a 2chloroethylphosphonic acid solution. The resin produced after 40 days and the aerial parts had their essential oils extracted in a Clevenger apparatus and the volatile chemical constituents were analyzed using GC/MS. The non-oxygenated sesquiterpenes $\alpha$-copaene $(21.15 \%)$ and $\alpha$-gurjunene (13.69\%), in addition to the oxygenated sesquiterpene spathulenol (10.32\%), were detected as the majority constituents of the essential oil of the leaves, and a concentration similar to that of $\alpha$-gurjunene was found in the branches (13.28\%). The resin essential oil showed a high concentration of hydrocarbon monoterpenes (76.49\%) with a predominance of $\alpha$-pinene (17.57\%) and limonene (46.11\%). Four gall morphotypes were found associated with this species. The present study reports for the first time information on the volatile constituents and the resinous potential of $P$. aracouchini, and registers the morphotypes of the galls that help in the taxonomy of the species.
\end{abstract}

Keywords: Exudation, essential oils, limonen, sesquiterpenes.

\section{Avaliação dos constituintes voláteis, exsudação de resina e ocorrência de galhas em Protium aracouchini (Aubl.) Marchand}

\begin{abstract}
Resumo
Protium aracouchini (Aubl.) Marchand [sin Icica aracouchini Aubl.] ocorrente na Reserva Florestal Adolpho Ducke, Amazônia Brasileira foi avaliada quanto a presença de galhas, a exsudação de resina e composição dos óleos essenciais das partes aéreas e resina. $\mathrm{O}$ experimento para estímulo à exsudação de resina no tronco foi conduzida utilizando-se uma solução de ácido 2-cloroetilfosfônico. A resina produzida após 40 dias e as partes aéreas foram submetidas à extração de óleos essenciais em Clevenger e os constituintes químicos voláteis analisados por CG/EM. Os sesquiterpenos não oxigenados, $\alpha$-copaeno $(21,15 \%)$ e $\alpha$-gurjuneno (13,69\%), além do sesquiterpeno oxigenado espatulenol (10,32\%), foram detectados como os constituintes majoritários no óleo essencial das folhas, concentração similar ao $\alpha$-gurjuneno foi encontrada nos galhos (13,28\%). O óleo essencial da resina mostrou alta concentração de hidrocarbonetos monoterpênicos $(76,49 \%)$ predominando o $\alpha$-pineno $(17,57 \%)$ e o limoneno $(46,11 \%)$. Quatro morfotipos de galhas foram encontrados associadas a esta espécie. O presente estudo relata, pela primeira vez, o conhecimento sobre os constituintes voláteis e o potencial resinífero de $P$. aracouchini bem como registra os morfotipos das galhas que auxiliam na taxonomia da espécie.
\end{abstract}

Palavras-chave: Exsudação, limoneno, óleos essenciais, sesquiterpenos.

\section{Introduction}

The Protium Burm f. genus (Burseraceae) is constituted of arboreal species of great importance in the Amazonian landscape and one of its striking features is the presence of aromatic resins that are exuded from various species of the genus. The Amazon is the main center of diversity of this genus, which is represented by about 73 species (Daly, 1992). In the Adolpho Ducke Forest Reserve near ManausAM (AM-010, Km 26), 24 species were identified in an inventoried area of $100 \mathrm{~km}^{2}$. In this fragment of the Amazonian Rainforest, Protium species occur in different environments and the presence of resins on the trunks and branches on the leaves of several individuals have been 
reported (Ribeiro et al., 1999).

Resins from Protium species usually exude from the trees as a milky liquid that coagulates on the trunk and may darken depending on the degree of oxidation. Studies related to the volatile components of the resins collected in the Adolpho Ducke Reserve have been performed for $P$. decandrum (Carvalho et al., 2010), P. hebetatum (Pinto et al., 2010, Ramos et al., 2000, Santana et al., 2020), P. altsonii (Ramos et al., 2000, Santana et al., 2020), P. spruceanum, P. paniculatum var. riedelianum and $P$. paniculatum var. new (Ramos et al., 2000). However, in studies with $P$. hebetatum "Brazilian elemi" it was evident that the resin produced in large quantities on the tree trunk was associated with the presence of insects that stimulated continuous exudation (Pinto et al., 2010). According to experiments conducted by Lima et al. (2016), resin exudation in large quantities in trees of this species can also stimulated by the use of the hormone ethephon.

Ribeiro et al. (1999) registered 12 species of Protium in the Adolpho Ducke Reserve as being hosts of galls and suggest that they can be used as a tool for the identification of these species because they seem extremely specific to their host. Galls consist of atypical transformations of plant tissues, hypertrophy and/or hyperplasia caused by the development of numerous organisms, mainly insects in the larval or pupal state (Fernandes et al., 1988). In the species Protium aracouchini (Aubl.) Marchand [sin Icica aracouchini Aubl.], we observed the presence of galls and an absence of resin in its individuals from the Adolpho Ducke Forest Reserve. Thus, this work aimed to induce its resin production, evaluate its volatile chemical components and register the morphotypes of its galls.

\section{Materials and Methods}

The fieldwork was carried out in a plateau forest of the Adolpho Ducke Forest Reserve where seven individuals of Protium aracouchini were located for the verification of galls and their resin production. In all individuals observed, there were no signals of the presence of resins on the trunks, thus, individual number 1657 was selected to stimulate resin production. In addition, leaves and branches were collected for the extraction of essential oils. To stimulate resin exudation, a hole of $0.5 \mathrm{~cm}$ diameter was made in the trunk at a height of $1.30 \mathrm{~m}$ and an ethephon (2-chloroethylphosphonic acid) water solution of $0.4 \mathrm{mg} / \mathrm{mL}$ was used. For the control, only distilled water was used. Resins were collected 40 days after the experiment and then this tree was observed for a period of 6 months. Samples of branches collected from four individuals were placed in plastic bags and transported to the Laboratory of Plant Taxonomy at the National Institute for Amazonian Research (INPA) where galls, which had previously been separated into individual morphotypes were photographed.

For the extraction of essential oils, samples of leaves and branches were dried for seven days in an air-conditioned environment, chopped, ground and then submitted to extraction by hydrodistillation in a Clevenger apparatus for four hours. The freshly exuded resin was subjected to the same extraction conditions.

The analysis of the volatile constituents were performed on a GC-MS (QP5000, Shimadzu), operating by electron impact
$(70 \mathrm{eV})$, which used a DB-5 $(30 \mathrm{~m} \times 0.25 \mathrm{~mm} \times 0.25 \mu \mathrm{m})$ capillary column in the GC experiment. The operating conditions were as follows: carrier gas was helium (flow 10 $\left.\mathrm{mL} \cdot \mathrm{min}^{-1}\right)$; temperature was set at $60-240{ }^{\circ} \mathrm{C}\left(3{ }^{\circ} \mathrm{C} \cdot \mathrm{min}^{-1}\right)$; injection size of $1.0 \mu \mathrm{L}$; sample injection temperature was $250{ }^{\circ} \mathrm{C}$; detector temperature $290{ }^{\circ} \mathrm{C}$; split 1:20. The compounds were identified by comparing their mass spectrum to those of the database of the GC-MS (NIST 62.lib), literature (Mc Lafferty and Stauffer, 1989) and retention indices (Adams, 2007). Quantitative analysis was performed using a gas chromatograph (GC 2010 GC-FID Shimadzu, Japan) under the same conditions as the GC-MS method.

\section{Results and Discussion}

The trunk of tree No. 1657 had exuded $24.4 \mathrm{~g}$ of resin in the 40 days after the application of ethephon. However, after this collection, there was no further exudation during the six month observation period. The yield of resin essential oil was considered high $(13.93 \%)$ and, in the leaves and branches, the yields were 0.35 and $0.02 \%$, respectively. In previous studies with resin collected from $P$. hebetatum in the Adolpho Ducke Reserve and stimulated by ethephon, the content was between 18.22-22.17\% (Lima et al., 2016). It is noteworthy that these species are considered naturally resiniferous when compared with $P$. aracouchini.

In the analysis of the essential oil of the leaves, an absence of monoterpenes was noted, though these were found in a low percentage $(3.12 \%)$ in the essential oil of the branches, as shown in Table 1. The non-oxygenated sesquiterpenes $\alpha$-copaene $(21.15 \%)$ and $\alpha$-gurjunene $(13.69 \%)$, in addition to oxygenated sesquiterpene spathulenol (10.32\%), were detected as the majority compound in the leaves (Figure 1, Table 2).

Table 1. Percentage of terpenes identified in essential oils of Protium aracouchini.

\begin{tabular}{lccc}
\hline \multicolumn{1}{c}{ Mono and sesquiterpenes } & Leaves & Branches & Resin \\
\hline Hydrocarbon monoterpenes & - & $2.18(4)$ & $76.49(7)$ \\
Oxygenated monoterpenes & - & $0.32(1)$ & $6.31(2)$ \\
Hydrocarbon sesquiterpenes & $48.08(13)$ & $43.05(16)$ & $3.67(2)$ \\
Oxygenated sesquiterpenes & $28.31(5)$ & $41.83(9)$ & - \\
\hline
\end{tabular}

Parentheses - number of terpenes.

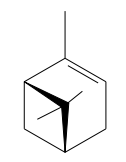

$\alpha$-pinene

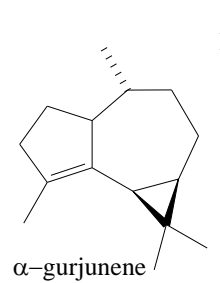

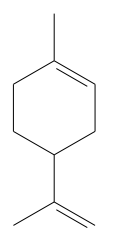

limonene

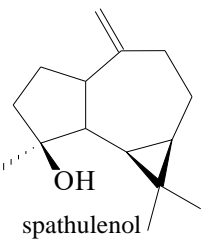

Figure 1. Chemical structures of the predominant monoterpenes and sesquiterpenes of essential oils obtained from $P$. aracouchini. 
Table 2. Chemical composition (\%) and retention index (RI) of essential oils from different parts of Protium aracouchini,

\begin{tabular}{|c|c|c|c|c|c|c|c|c|c|c|c|}
\hline Constituent & Leaves & Branches & Resin & $\begin{array}{c}\text { RI } \\
\text { EXP }\end{array}$ & $\begin{array}{c}\text { RI } \\
\text { LIT }\end{array}$ & Constituent & Leaves & Branches & Resin & $\begin{array}{c}\text { RI } \\
\text { EXP }\end{array}$ & $\begin{array}{c}\text { RI } \\
\text { LIT }\end{array}$ \\
\hline$\alpha$-pinene & & 1.17 & 17.57 & 931 & 939 & $\alpha$-humulene & 1.03 & 1.54 & & 1451 & 1454 \\
\hline sabinene & - & - & 2.79 & 971 & 976 & seychellene & 1.76 & 0.78 & - & 1458 & 1460 \\
\hline$\beta$-pinene & - & - & 5.74 & 976 & 980 & $\gamma$-muurolene & 1.27 & 0.75 & - & 1474 & 1477 \\
\hline myrcene & - & 0.19 & - & 988 & 991 & $\beta$-selinene & 2.09 & & - & 1484 & 1485 \\
\hline$o$-cymene & - & 0.17 & - & 1020 & 1022 & viridiflorene & - & 0.95 & - & 1493 & 1493 \\
\hline$p$-cymene & - & - & 4.28 & 1023 & 1026 & $\alpha$-muurolene & 0.57 & 0.69 & - & 1497 & 1499 \\
\hline limonene & - & 0.65 & 46.11 & 1026 & 1031 & cis-calamenene & 1.22 & 1.07 & - & 1520 & 1521 \\
\hline trans-anethole & - & 0.32 & - & 1278 & 1283 & $\delta$-cadinene & 0,97 & 4.11 & - & 1522 & 1524 \\
\hline 1,8-cineole & - & - & 4.24 & 1030 & 1033 & $\alpha$-calacorene & - & 1.26 & - & 1541 & 1542 \\
\hline carvone & - & - & 2.07 & 1246 & 1242 & ledol & - & 5.93 & - & 1567 & 1564 \\
\hline$\delta$-elemene & - & 1.12 & - & 1336 & 1339 & spathulenol & 10.32 & 6.48 & - & 1577 & 1576 \\
\hline$\alpha$-copaene & 21.15 & 7.07 & 1.78 & 1375 & 1376 & caryophyllene oxide & 4.58 & 7.65 & - & 1582 & 1581 \\
\hline$\beta$-bourbonene & - & 1.79 & - & 1383 & 1384 & $\beta$-copaene- $4 \alpha$-ol & 6.37 & 1.96 & - & 1591 & 1584 \\
\hline$\beta$-elemene & 0.69 & 2.75 & - & 1390 & 1391 & khusimone & 2.96 & 5.97 & - & 1594 & 1593 \\
\hline$\beta$-cubebene & - & - & 1.89 & 1391 & 1390 & 1-epi-cubenol & 0.97 & 1.25 & - & 1627 & 1627 \\
\hline$\alpha$-gurjunene & 13.69 & 13.28 & - & 1410 & 1409 & cubenol & - & 1.67 & - & 1641 & 1642 \\
\hline$\beta$-caryophyllene & 2.08 & 3.83 & - & 1418 & 1418 & cadalene & - & 1.58 & - & 1671 & 1674 \\
\hline$\alpha$-trans-bergamotene & 0.65 & - & - & 1437 & 1436 & $\alpha$-bisabolol & 3.11 & 9.34 & - & 1682 & 1683 \\
\hline$\alpha$-guayene & 0.91 & 2.06 & - & 1441 & 1439 & Total & 76.39 & 87.38 & 86.47 & - & - \\
\hline
\end{tabular}

RI EXP - retention index of experiment (coluna DB-5); RI LIT - retention index of experiment according Adams (2007).

This concentration is similar to the essential oil of the branches of $\alpha$-gurjunene $(13.28 \%)$. The resin essential oil showed a high concentration of hydrocarbon monoterpenes (76.49\%) with a predominance of $\alpha$-pinene $(17.57 \%)$ and limonene $(46.11 \%)$. Previous works with fresh resin collected in the Adolpho Ducke Forest Reserve showed high levels of limonene, which were detected in $P$. hebetatum (31.8014.95\%; Lima et al., 2016), P. strumosum (75.5\%; Zoghbi et al., 2005), and P. spruceanum (90.93\%) collected at the INPA campus (Lima et al., 2014). The comparison with essential oils from $P$. aracouchini leaves from Brazilian Northeast the difference of chemical profile of the volatile constituents was evidenced (Freitas et al., 2011, Souza et al., 2015).

Among the seven individuals of $P$. aracouchini found in the Adolpho Ducke Forest Reserve the presence of four distinct gall morphotypes was detected in four individuals (Figure 2) with sizes ranging from 0.6 to $2.0 \mathrm{~mm}$ in length.

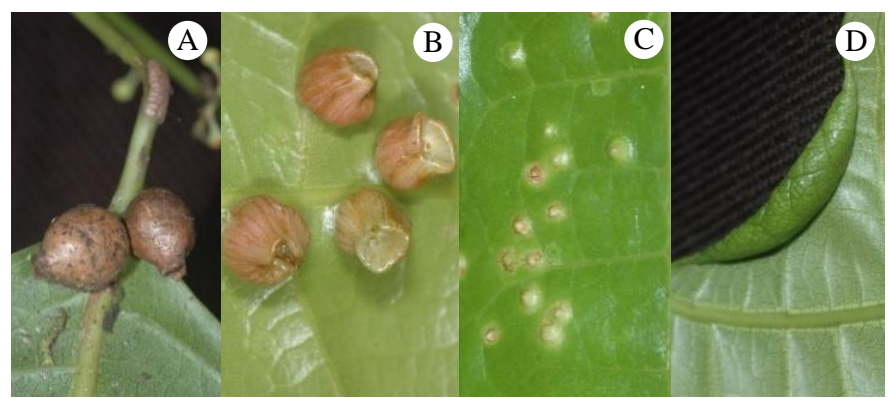

Figure 2. Gall morphotypes associated with $P$. aracouchini (Burseraceae): globoid (A and B), discoid (C) and curled edge (B) forms.
The collected leaf galls collected were globoid, curled edge and discoid forms, and brown and green coloring. All were glabrous. Fernandes (2010) found 98 gall morphotypes associated with Protium species in the Adolpho Ducke Forest Reserve, the majority of these galls occurred on leaves.

\section{Conclusion}

There appears to be a lack of literature regarding the chemical and biological properties of the species $P$. aracouchini and, as a result, this study has contributed to the knowledge gap regarding the composition of its volatile constituents from resin as well as the knowledge of the taxonomy of the species through records of the morphotypes of the galls found. The induction of resin production was also an opportunity to obtain raw material for the extraction of essential oils from resins that presented a different chemical profile to the essential oils from the aerial parts.

\section{References}

Adams, R. P. (2007). Identification of essential oil components by gas chromatography/mass spectroscopy ( $4^{\mathrm{a}}$ ed.). Carol Stream, Illinois: Allured Publishing Corporation.

Carvalho, L. E., Pinto, D. S., Magalhães, L. A. M., Lima, M. P., Marques, M. O. M., \& Facanali, R. (2010). Chemical constituents of essential oil of Protium decandrum (Burseraceae) from Western Amazon. Journal of Essential Oil Bearing Plants, 13(2), 181-184. doi: 10.1080/0972060X.2010.10643809

Carvalho, F. S. P. (2010). Insetos galhadores associados à família Burseraceae da reserva florestal Ducke, Manaus, Amazonas, Brasil. (Dissertação de Mestrado). Instituto Nacional de Pesquisas da Amazônia. Manaus, Amazonas.

Daly, C. D. (1992). New taxa and combinations in Protium Burm. f. Studies in neotropical Burseraceae VI. Brittonia, 44(3), 280-299. doi: 
https://doi.org/10.2307/2806927.

Fernandes, G. W. A., Tameirão-Neto, E., \& Martins, R. G. (1988). Ocorrência e caracterização de galhas entomógenas na vegetação do Campus Pampulha da Universidade Federal de Minas Gerais. Revista Brasileira de Zoologia, 5(1), 11-29. doi: 10.1590/S0101-81751988000100002.

Freitas, J. G. R., Camara, C. A. G., Moraes, M. M., \& Silva, H. C. H. Volatile constituents of two species of Protium from the atlantic rainforest in the state of Pernambuco, Brazil. (2011). Natural Product Communications, 6(11), 1727-1730. doi: 10.1177/1934578X1100601139

Lima, T. A. A. C., Rocha, K. R. A., Melo, M. F. F., Marques, M. O. M., Facanali, R., \& Lima, M. P. (2014). Caracterização morfológica e análise de voláteis da espécie resinífera Protium spruceanum (Benth.) Engl. do campus do INPA, Manaus-AM. Scientia Amazonia, 3(2), 6-10.

Lima, T. A. A. C., Ribeiro, J. E. L. S., Marques, M. O. M., Facanali, R., \& Lima, M. P. (2016). Estimulo para produção de resina em Protium hebetatum Daly e avaliação dos constituintes químicos voláteis. Scientia Amazonia, 5(3), 21-24.

Mclafferty, F. W., \& Stauffer, D. (1989). The Wiley/NBS Registry of Mass Spectral Data. New York: Wiley -Interscience Pub.

Pinto, D. S., Carvalho, L. E., Lima, M. P., Marques, M. O. M., Facanali, R., \& Ribeiro, J. E. L. S. (2010). Volatiles of foliar rachis, branches and resin elicited by insects from Protium hebetatum grows wild in Amazon. Journal of Essential Oil Bearing Plants, 13(6), 699-703. doi: 10.1080/0972060X.2010.10643881.

Ramos M. F. S., Siani, A. C., Tappin, M. R. R., Guimarães, A. C., \& Ribeiro, J. E. L. S. (2000). Essential oils from oleoresins of Protium spp. of the Amazon region. Flavour and Fragrance Journal, 15(6), 383-387. doi: 10.1002/1099-1026(200011/12)15:6<383::AID-FFJ927>3.0.CO;2-X

Ribeiro, J. E. S., Hopkins, M. J. G., Vicentini, A., Sothers, C. A., Costa, M. A. S., Brito, J. M., Souza, M. A. D., Martins, L. H. P., Lohmann, L. G., Assunção, P. C. L., Pereira, E. C., Silva, C. F., Mesquita, M, R., \& Procópio, L. C. (1999). Flora da Reserva Ducke: Guia de Identificação das Plantas Vasculares de uma Floresta de Terra-firme na Amazônia Central. Manaus: INPA/DFID (Eds.), Manaus-Amazonas.

Santana, R. C., Santos Rosa, A. S., Mateus, M. H. S., Soares, D. C., Atella, G., Guimarães, A. C., Carlos Siani, A. C., Ramos, M. F. S., Saraiva, E. M., \& Silva, L. H. P. (2020). In vitro leishmanicidal activity of monoterpenes present in two species of Protium (Burseraceae) on Leishmania amazonenses. Journal of Ethnopharmacology, 15, 112981. doi: 10.1016/j.jep.2020.112981.

Souza, L. R., Trindade, F. G., Oliveira, R. A., Costa, L. C. B., Gomes, V. M., \& Cunha, M. (2016). Histochemical characterization of secretory ducts and essential oil analysis of Protium species (Burseraceae). Journal of Essential Oil Research, 28(2), 166-171. doi: 10.1080/10412905.2015.1092478

Zoghbi, M. G. B., Andrade, E. H. A., Lima, M. P., Silva, T. M. D., \& Daly, D. C. (2005). The essential oils of five species of Protium growing in the north of Brazil. Journal of Essential Oil Bearing Plants, 8(3), 312-317. doi: 10.1080/ 0972060X. 2005.10643458.

License: Creative Commons CC BY NC 4.0 